\title{
Christian Magazine on Czech Television and Topics from the Constitution Gaudium et spes
}

\section{Bedřich Jetelina}

\section{Introduction}

At the Second Vatican Council the Roman Catholic Church embraced responsibility for this world and expressed its responsibility in the Pastoral Constitution on the Church in the Modern World Gaudium et spes. ${ }^{1}$ The second part of this constitution identifies "a number of particularly urgent needs characterizing the present age" 2 to which the Church ought to react and in particular states: "it may be helpful to concentrate on these: marriage and the family, human progress, life in its economic, social and political dimensions, the bonds between the family of nations, and peace."

This paper aims to show how informing about how the Church reacts to these problems and helps to solve them was reflected in 2012-2015 in the programme Christian Magazine, broadcast by the public service Czech Television. The text therefore does not deal with how the Church puts the incentives of the second part of Gaudium et spes into practice, but merely with the media image of this effort, created by the producers and authors of the public service medium specializing in the religious sphere. Since Czech Television is not, and by law cannot be, subordinate to the purposes of any church, the findings show especially how interesting and attractive these topics are for a public service medium.

The fact that Christian Magazine reflects religious life in a systematic manner ensures that these are not accidentally processed contributions under the influence of momentary demand, but an image presented on a long-term basis. In the media age, however, a section society perceives this image as the image of reality.

\section{The paper therefore provides answers to three questions:}

1) What space does the Roman Catholic Church receive in the broadcasting of a Christian-oriented programme of public service television?

2) What part of the broadcasting of Christian Magazine devoted to the Roman Catholic Church was taken up by coverage reflecting "particularly urgent needs characterizing the present age"?

3) How were "particularly urgent needs characterizing the present age" presented in reports concerning non-Catholic churches and ecumenical issues?

At http://www.vatican.va/archive/hist_councils/ii_vatican_council/documents/vat-ii_cons_19651207_gaudium-et-spes_en.html. Further only GS and paragraph number. 


\section{Choice of the programme Christian Magazine as the investigated medium}

The religious broadcasting of Czech Television is fairly broad. Besides Christian Magazine it includes transmission of divine services, the programme series Paths of Faith, A Festive Word and the talk show Through the Eye of a Needle. Solitary religious documents and small cycles appear in broadcasting several times a year. Religious issues are also covered in the news section or enter other reports, documentaries and features. ${ }^{4}$

The series Christian Magazine was selected especially for its format. It is a religious news and reporting programme, systematically focusing on the life of churches and religious societies. ${ }^{5}$ While other religious cycles depend to a great extent on the author's artistic handling of the topic (Paths of Faith), decision of an individual speaker (A Festive Word), or personality of the guest (Through the Eye of a Needle), Christian Magazine arises as an intersection of the creative perception of the authors and producers of Czech Television with the offer of the churches, motivated by their effort to medialize topics they regard as important.

Topics included in the broadcasting of Christian Magazine therefore reflect the reality of religious life of which the churches themselves are to a great extent interested to inform us. ${ }^{6}$ This offer of the churches is then editorially processed from the point of view of a public service medium, ${ }^{7}$ which means also with respect to how the authors of the programme regard the particular religious activity as interesting for the broader Czech public. Christian Magazine is not an investigative programme or one critical regarding the churches. The programme ensures an ecumenical a variety, as well as variety of topics and a unified attitude, quite positive to religion. ${ }^{8}$ Its content can metaphorically be described as a public service medium mirror reflecting the activities of Czech religious life.

The temporal extension of the investigated period $2012-2015^{9}$ was stipulated with regard to the fact that in 2012 a new system of creative production groups became operative in Czech Television and the Creative Production Group of Religious Creation (creative producer Patrick Diviš) was established ${ }^{10}$ responsible for producing Christian Magazine. The period of four years encompasses a sufficiently long period to capture the relevant trends and at the same time not yield data reflecting merely reactions to topical events, such as church restitutions, the synod on the family or the refugee crisis.

4 See Czech Television, Náboženské pořady (on-line), at http://www.ceskatelevize.cz/porady/tema/nabozenske/, accessed December 10 ${ }^{\text {th }}$, 2015.

5 "In its visual field there are both world events with a religious undertone and moments and activities in which the world of the national churches encounters Czech society. It does not wish to avoid even the inconspicuous enterprises of church, charity and diaconic associations in the individual regions of the Czech Republic." Czech Television, Krestanský magazin (on-line), at http://www. ceskatelevize.cz/porady/1098528273-krestansky-magazin/, accessed December 10 $10^{\text {th }}, 2015$.

6 "The press center of the Czech Bishops' Conference informs us of current events in the Church home and abroad. At the same time it notifies us of interesting events, lectures, media programms, publications and new Church documents." Press center of Czech Bishops' Conference (on-line), at http://tisk.cirkev.cz/registrace-uzivatele/, accessed December $10^{\text {th }}, 2015$.

7 The law defines this point of view as "producing and broadcasting programmes and providing a balanced offer of programmes for all population groups with respect to the freedom of their religious faith and belief, culture, ethnic or nationality background, national identity, social background, age or sex, so that these programmes reflect the variety of views and political, religious, philosophical and artistic orientations, with the goal of reinforcing mutual understanding and tolerance and supporting the cohesion of a pluralist society." Law 483/1991 Coll. \$2, par. 2, letter c.

8 See Czech Television, Křestanský magazín.

9 Due to the deadline for submitting the paper the reports of 2015 were processed only up to November 2015.

10 Czech Television, Patrick Diviš (on-line), at http://www.ceskatelevize.cz/lide/patrick-divis/, accessed December $10^{\text {th }}, 2015$. 


\section{Choice of content analysis as an investigation method}

The selected method for collecting data is content analysis because the choice of the investigated programme, its orientation and long-term effect on the viewer all eliminate certain limitations of the methodology. ${ }^{11}$ Since all broadcasted Christian Magazines are available on the web site of Czech Television ${ }^{12}$ the data obtained by content analysis can easily be verified. The news and report approach of the authors with a prevalently positive attitude to the churches to a great extent eliminates the risk that the method will not capture deeper contexts and effect of the individual reports that would be captured by some of the qualitative analytical methods. ${ }^{13}$

The selected coding unit of content analysis is one reports..$^{14}$ The coding key is a double division of reports into categories. The first division is based on which denomination is involved in the main topic of the report (Roman Catholic, one of the Protestant denominations, an ecumenical issue or an issue concerning non-Christian religions). The second division derives from how the individual contributions reflect the "particularly urgent needs characterizing the present age". This division was further specified as follows:

1) The "particularly urgent need characterizing the present age" had to be the main topic of the report. The decision whether that is or is not the case was made upon viewing the report and analyzing its content and effect. If the report concerned several issues, only the main topic was included in the statistics.

2) Denomination membership had to be clearly stipulated - i.e., it had to be distinguished whether the report concerns an activity directly initiated by or associated with the Roman Catholic Church, with the activity of other communities, or with an ecumenical activity.

3) With respect to the spirit of the constitution Gaudium et spes the "particularly urgent needs characterizing the present age" had to be televisually introduced with an overlap with society and were not to concern merely common religious life. ${ }^{15}$

\section{Results of content analysis}

Christian Magazine has no strict central production team and the individual parts of the series are produced quite independently by studios in Prague, Brno and Ostrava. ${ }^{16}$ Table 1 shows the number of minutes of report time and number of reports produced by the individual studios in the investigated period.

11 "Content analysis assumes that meaning lies at the manifest level of content, it is superficial, evident and unambiguous and as such can be read and grasped by a quantitative investigative procedure. That involves the assumption that the amount of attention the examined text devotes to a certain topic is an expression of the importance attributed to it by the presenter and the social framework, and therefore that quantification, numeric expression of the ratio of certain elements in a text (e.g. the number of words or extent of space/time devoted to a certain topic) is a reliable indicator of the meaning of the message under scrutiny." Renáta SEDLÁKOVÁ, Výzkum médií, Praha: Grada Publishing, 2014, p. 293.

12 Cf. Czech Television, Křestanský magazín.

13 The issue of qualitative analysis will be mentioned in the concluding discussion.

14 Since the individual reports are of different lengths, it was to be considered whether the coding unit to be selected ought not to be time devoted to an issue, rather than number of reports. "Report" was selected especially for easier data verification.

15 Otherwise almost all reports could be classified under the heading of "culture", since e.g. ecclesial buildings are always somehow linked to culture. But reports about the reconstruction of churches, architecture or organs are not included in the group 'culture' if they lacked a broader social 'overlap'.

16 Cf. Czech Television, Křestanský magazín. 
The studio in Brno had most space in the broadcasting as far as time is concerned. The Prague studio produced the highest number of reports and therefore the programmes most varied in content. Graph 1 shows the measured results expressed as percentages.

\section{Table 1: Reports and report time in 2012-2015 according to the individual studios}

\begin{tabular}{lccc} 
& Brno & Prague & Ostrava \\
\hline Reports (number) & 386 & 445 & 182 \\
\hline Report time (min) & 1600 & 1375 & 900
\end{tabular}

Graph 1: Percentage expression of the number of reports and report time in 2012-2015

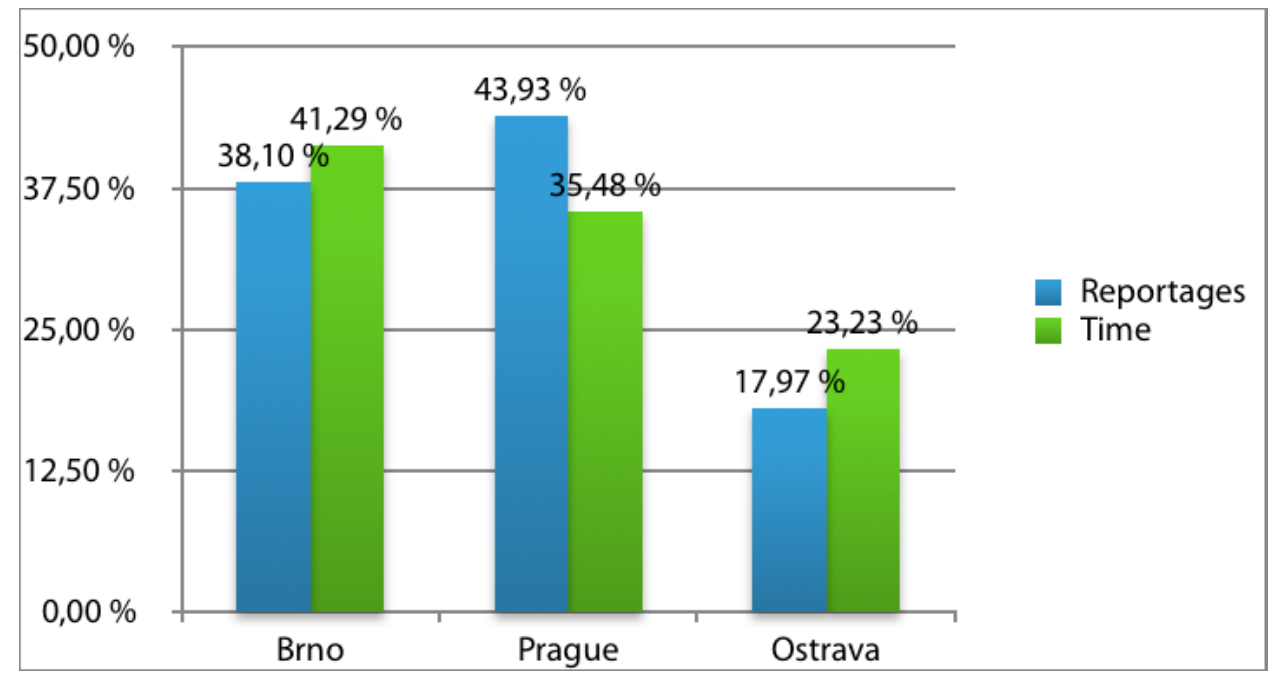

The measured values from Table 2 and Graph 2 confirm what the authors of Christian Magazine say themselves, viz. that each studio prefers different issues. ${ }^{17}$ The Prague authors take most interest in issues of ecumenical dialogue. The Brno studio gives about as much space to non-Catholic churches as Prague does, but compared to Prague it devotes about half the interest to issues of ecumenical dialogue. The space taken up in Prague by ecumenical dialogue is in the Brno broadcasting taken up by the Roman Catholic Church. In the Ostrava broadcasting, ecumenical dialogue makes up a mere $8 \%$ of contributions and reports concerning non-Catholic churches $15 \%$; Roman Catholic topics are therefore unambiguously dominant.

If we consider Christian Magazine as a whole, reports of Roman Catholic activities make up about $56 \%$ of the broadcasting, ecumenical dialogue just under $26 \%$ of the broadcasting and reports concerning non-Catholic communities just above $18 \%$ of the broadcasting.

The differences in the production of the individual studios can be due to different reasons. The first that comes to mind is of course that the programme's composition is affected by the studio's location. Prague, being the capital of the Czech Republic, is the seat of all of the churches' headquarters and important ecumenical activities naturally take place there. Prague is also to a great extent a secular place, while the Moravian lands are more religious and traditionally more Catholic. But Christian Magazine's composition can also be influenced by the fact that in Ostrava the programme is produced in cooperation with the Ostrava studio Telepace, which produces programmes for the Catholic Television Noe, ${ }^{18}$ or that the producer of the Prague edition was a minister of the Evan- 
gelical Church of Czech Brethren. ${ }^{19}$ Of course, considering the public service character of Czech Television these aspects ought not to be significant, but they must also be taken into account.

If we consider the measured data from the point of view of statistical data of the religious faith of the population, the programme composition of the Ostrava studio best reflects the data of the last census with respect to the Roman Catholic Church, if we define that Christian Magazine is intended only for viewers professing adherence to a church (of them $74 \%$ profess adherence to the Roman Catholic Church). ${ }^{20}$ But if the programme was meant not only for a strictly church audience, but also for people somehow professing religion, then the denominational composition closest to the reality of the Czech society is the one presented by the Prague studio (approximately $50 \%$ of persons professing religion profess adherence to the Roman Catholic Church).

Table 2: Number of published reports from the point of view of representing the individual denominations in 2012-2015

\begin{tabular}{c|ccc} 
& $\begin{array}{c}\text { Reports concerning the } \\
\text { Roman Catholic Church }\end{array}$ & $\begin{array}{c}\text { Reports concerning } \\
\text { ecumenical issues }\end{array}$ & $\begin{array}{c}\text { Reports concerning other } \\
\text { churches and religions }\end{array}$ \\
\hline Brno & 243 & 71 & 72 \\
\hline Ostrava & 140 & 15 & 27 \\
\hline Prague & 188 & 173 & 84 \\
\hline Total & $\mathbf{5 7 1}$ & $\mathbf{2 5 9}$ & $\mathbf{1 8 3}$ \\
\hline
\end{tabular}

Graph 2: Percentage expression of published reports from the point of view of representing the individual denominations in 2012-2015

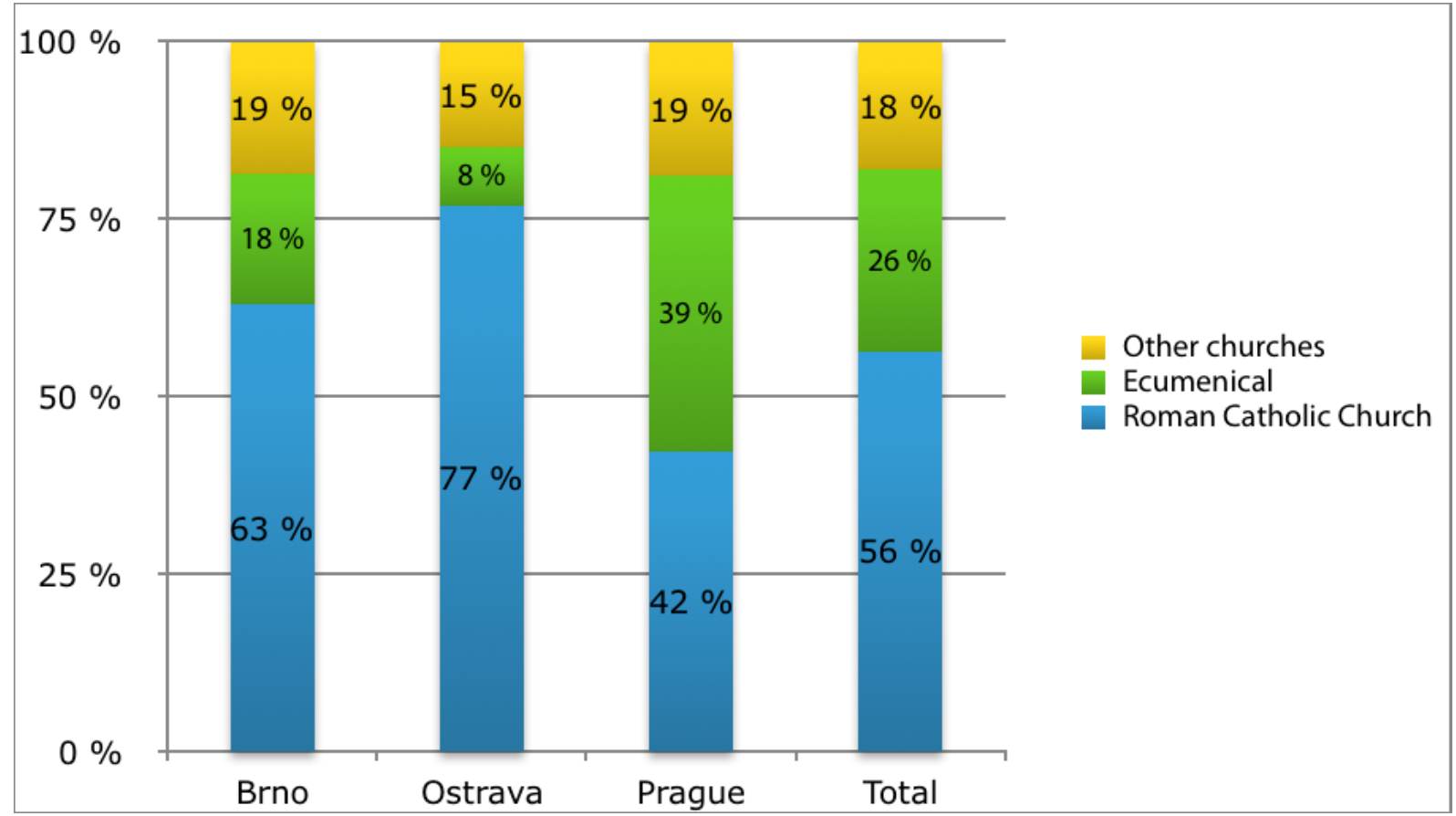

Table 3 and Graph 3 imply that the space devoted by the individual studios to "particularly urgent

19 Cf. Czech Television, Michael Otř́sal (on-line), at http://www.ceskatelevize.cz/lide/michael-otrisal/, accessed December $13^{\text {th }}, 2015$.

20 According to the census $74 \%$ of the total number of persons professing adherence to a church adhere to the Roman Catholic Church (cf. ČESKÝ STATISTICKÝ ÚŘAD, Náboženská víra obyvatel podle výsledků sčítání lidu, Lidé a společnost, 2014, p. 41). 
needs characterizing the present age" (designated in the tables and graphs with the Constitution's abbreviation "GS") in contributions concerning the Catholic Church is about the same, although most interest is taken in this in Ostrava. But if we take a look at their further division (Table 4), we see a marked difference between Prague and the two Moravian studios. While Ostrava and Brno almost exclusively pay attention to the development of culture, Prague also takes notice of political issues and peace.

Table 3: Number of reports concerning the Roman Catholic Church unambiguously devoted to "needs characterizing the present age" from the constitution Gaudium et spes in 2012-2015

\begin{tabular}{ccc} 
& GS & Other \\
\hline Brno & 85 & 301 \\
\hline Ostrava & 50 & 132 \\
\hline Prague & 100 & 345 \\
\hline Total & $\mathbf{2 3 5}$ & $\mathbf{7 7 8}$ \\
\hline
\end{tabular}

Graf 3: Percentage expression of the number of reports concerning the Roman Catholic Church unambiguously devoted to "needs characterizing the present age" from the Constitution Gaudium et spes in 2012-2015

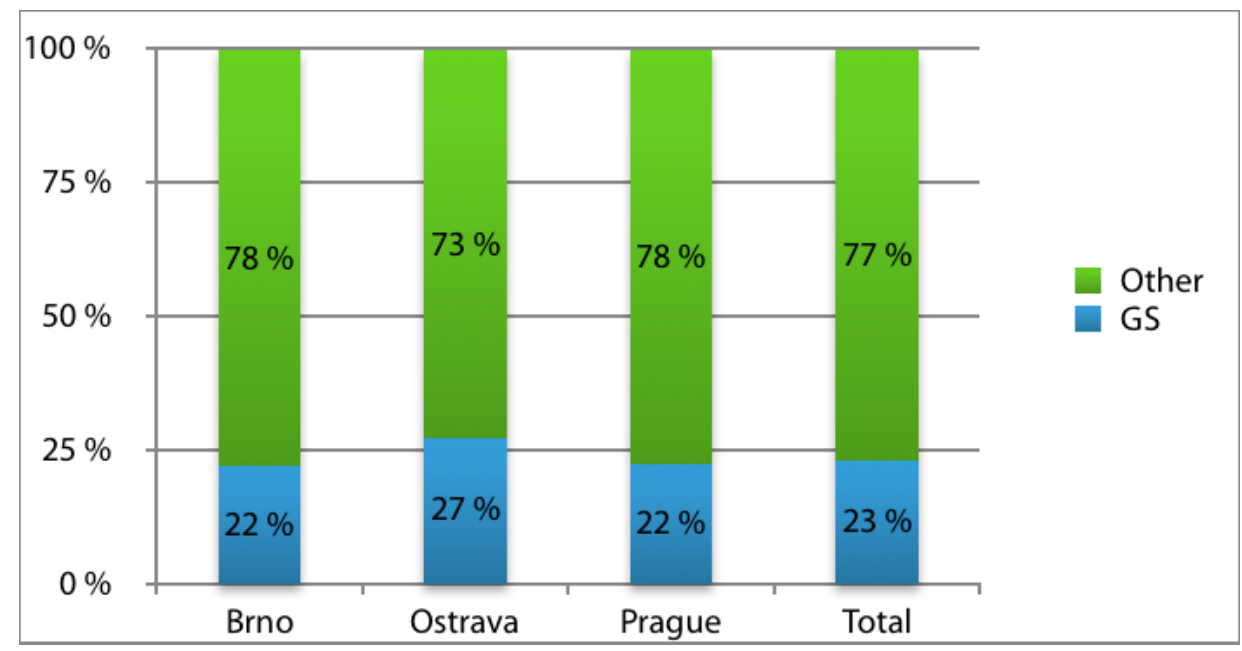

Table 4: Classification of the "needs characterizing the present age" by topic in reports concerning the Roman Catholic Church in 2012-2015

\begin{tabular}{ccccccc} 
& $\begin{array}{c}\text { Marriage } \\
\text { and family }\end{array}$ & $\begin{array}{c}\text { Development } \\
\text { of culture }\end{array}$ & $\begin{array}{c}\text { Economic } \\
\text { and social life }\end{array}$ & Politics & $\begin{array}{c}\text { Peace and } \\
\text { community } \\
\text { of nations }\end{array}$ \\
\hline Brno & 5 & 79 & 0 & 0 & 1 \\
\hline Ostrava & 5 & 42 & 0 & 2 & 1 \\
\hline Prague & 7 & 52 & 1 & 15 & 25 \\
\hline Total & $\mathbf{1 7}$ & $\mathbf{1 7 3}$ & $\mathbf{1}$ & $\mathbf{1 7}$ & $\mathbf{2 7}$ \\
\hline
\end{tabular}


Table 5 and Graph 4 show that in non-Catholic contributions "particularly urgent needs characterizing the present age" as a whole are again most reflected by the studio in Ostrava, and least by the one in Brno. At the same time they imply that non-Catholic communities deal with these issues less than Catholic ones do.

Table 5: Number of reports concerning ecumenical issues and non-Catholic churches unambiguously devoted to "needs characterizing the present age" in 2012-2015

\begin{tabular}{ccc} 
& GS & Other \\
\hline Brno & 27 & 143 \\
\hline Ostrava & 11 & 42 \\
\hline Prague & 60 & 257 \\
\hline Total & $\mathbf{9 8}$ & $\mathbf{4 4 2}$ \\
\hline
\end{tabular}

Graf 4: Percentage expression of the number of reports concerning ecumenical issues and non-Catholic churches unambiguously devoted to "needs characterizing the present age" in 2012-2015

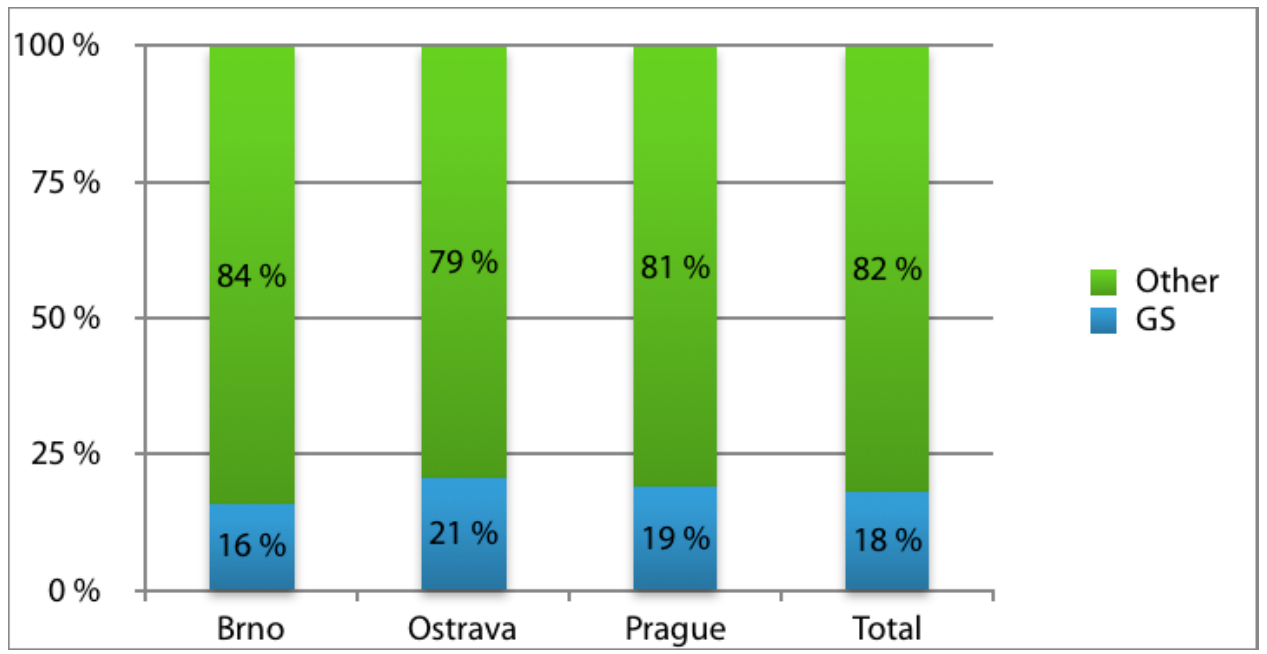

Tables 6 and 7 along with Graph 5 supplement the overall view by showing the overall number of reports devoted to "particularly urgent needs characterizing the present age" regardless of denominational membership.

Table 6: Total number of reports devoted to "needs characterizing the present age" in 2012-2015

GS

112

66

160

338
Other

274

116

Prague

Total

675 
Graph 5: Percentage expression of the number of reports devoted to "needs characterizing the present age" in 2012-2015

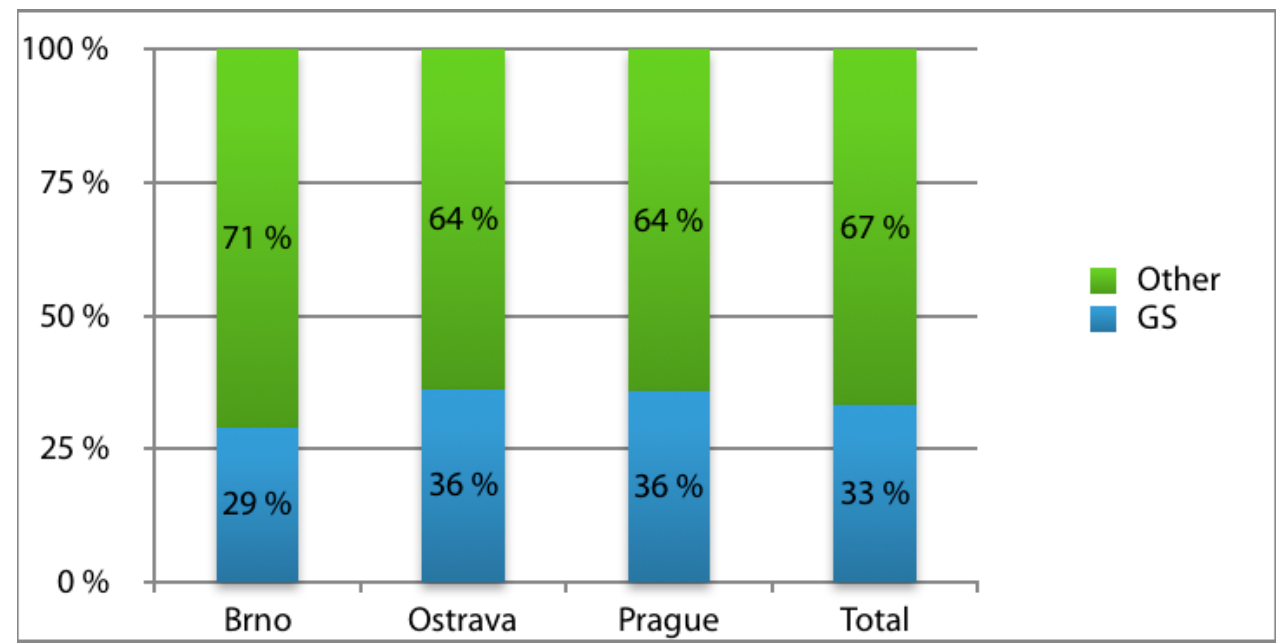

Table 7: Classification of "needs characterizing the present age" in reports regardless of denominational membership in 2012-2015

\begin{tabular}{ccccccc} 
Studio & $\begin{array}{c}\text { Marriage } \\
\text { and family }\end{array}$ & $\begin{array}{c}\text { Development } \\
\text { of culture }\end{array}$ & $\begin{array}{c}\text { Economic } \\
\text { and social life }\end{array}$ & Politics & $\begin{array}{c}\text { Peace and } \\
\text { community } \\
\text { of nations }\end{array}$ \\
\hline Brno & 8 & 101 & 0 & 0 & 3 \\
\hline Ostrava & 5 & 53 & 0 & 2 & 1 \\
\hline Prague & 12 & 93 & 1 & 20 & 34 \\
\hline Celkem & 25 & 247 & 1 & 22 & 38 \\
\hline
\end{tabular}

\section{For discussion}

As the data in Table 3 show, only 23\% of the reports concerning the Roman Catholic Church in Christian Magazine are devoted to "particularly urgent needs characterizing the present age". Since three independent production teams prepare the programmes and the measured values are almost the same, there is nothing to suggest that selection of the report topics is influenced by some bias against "particularly urgent needs characterizing the present age", but rather that it reflects the media offer of the Church. This fairly low percentage may mean that:

1) the Roman Catholic Church does not regard "particularly urgent needs characterizing the present age" as a crucial part of media communication;

2) the Roman Catholic Church does regard communication concerning "particularly urgent needs characterizing the present age" as crucial, but the public service television does not reflect this effort. The reason could be (since intentional ignoring on the part of Czech Television has been ruled out above) that the Church does not offer those topics in a form that is attractive for a public service medium. These two hypotheses could be confirmed or falsified especially by analyzing press reports and media outputs of the Czech Bishops' Conference and the individual dioceses. 
Besides the (fairly low) percentage of reports devoted to "particularly urgent needs characterizing the present age", the content analysis leads us to conclude that Christian Magazine barely takes notice of issues of economic and social life and only minimally reflects family or political and peace issues, while most contributions are devoted to culture. ${ }^{21}$ Non-Catholic churches touch upon "particularly urgent needs characterizing the present age" even less.

These numbers must not be perceived absolutely and categorical judgments deduced from them. ${ }^{22}$ Nonetheless, the results of the content analysis could serve church officials responsible for contact with the media as an incentive for reflection as to whether it is necessary to change the way of presenting "particularly urgent needs characterizing the present age" so that they become more attractive for television.

On the other hand, Czech Television as a public service institution obviously needs not take much heed of the constitution Gaudium et spes. But the content analysis could also serve as an incentive for reflection to the production of Christian Magazine, whether presenting religious issues in a broader social context, to which the constitution Gaudium et spes inspires, would not make religious television programmes more attractive for a broader constituency of viewers.

\title{
Christian Magazine on Czech Television and Topics from the Constitution Gaudium et spes
}

\begin{abstract}
The paper analyzes episodes of the Christian Magazine programme broadcast in 2012-2015 by the public service Czech Television. The content analysis aims to find out how and to what extent this news and reporting programme reflects the "particularly urgent needs characterizing the present age" mentioned in the second part of the Pastoral Constitution on the Church in the Modern World Gaudium et spes. "Particularly urgent needs characterizing the present age" are the main topic of only $23 \%$ of the reports broadcast during the investigated period, most of them dealing with cultural issues. Despite the restrictions of content analysis as compared to qualitative methods of research the results may serve as an incentive for reflection not only on the form of presenting "particularly urgent needs characterizing the present age" on the part of the Church, but also for reflection on the part of Czech Television.
\end{abstract}

Keywords: Gaudium et spes, content analysis, particularly urgent needs characterizing the present age, Czech Television, Roman Catholic Church

\section{Contact}

\section{Dr. Bedřich Jetelina}

University of South Bohemia in České Budějovice

Faculty of Theology, Centre of Media Education

Kněžská 8, 37001 České Budějovice

jetelina@gmail.com

21 Of course the topic of culture is much closer to a television programme of this type than topics following more complex realities.

22 E.g., a whole number of reports are devoted to the work of Charita, where some of the "particularly urgent needs characterizing the present age" are mentioned in a partial way, especially issues of marriage, family, or economic policy, but the methodology of the investigation did not make it possible to take these into account, as they were not the main topic of the reporting. 